\title{
Diversity of Ethnomedicinal Plants in Boridand Forest of District Korea, Chhattisgarh, India
}

\author{
Ramesh Kumar Ahirwar \\ Department of Botany, Govt. College Birsinghpur Pali, Umaria, India \\ Email: dr.rkahirwar@gmail.com
}

Received 20 January 2015; accepted 14 February 2015; published 16 February 2015

Copyright (C) 2015 by author and Scientific Research Publishing Inc.

This work is licensed under the Creative Commons Attribution International License (CC BY).

http://creativecommons.org/licenses/by/4.0/

(c) (i) Open Access

\begin{abstract}
Present study deals with an extensive ecological assessment of natural forest areas under several in-situ conservation plots which have resulted from high rate of grazing and biotic pressure. Overexploitation of forest and unwanted incidental fire cases decreased the diversity of several ethnomedicinally and economically valuable plants species from the Boridand forest region in Korea district, Chhattisgarh. The total number of plants reported in all three study sites, 41 plants species belonging to 26 families and 37 plant genera were identified. A field survey was conducted at three different study sites in Boridand forest, district Korea, Chhattisgarh as Plot A, Plot B and Plot C, during months March 2013 to February 2014 to identify the diversity of ethnomedicinal plants.
\end{abstract}

\section{Keywords}

Diversity, Conservation, Ethnomedicinal, Boridand Forest, Chhattisgarh

\section{Introduction}

Boridand forest is a beautiful hill station in the district Korea. There is also one of world lable mini Railway Junction (BRND) of South Eastern Central Railway (SECR). It is border line of Madhya Pradesh and Chhattisgarh State. Korea district lies between $23^{\circ} 02^{\prime} 42^{\prime \prime}$ to $23^{\circ} 44^{\prime} 46^{\prime \prime}$ north latitude and between $81^{\circ} 46^{\prime} 42^{\prime \prime}$ to $82^{\circ} 33^{\prime} 43^{\prime \prime}$ east longitude. Its height from sea level is 700 meters. Total area of the district is $5978 \mathrm{sq}$. km. The climate is ideal with a beautiful monsoon, a mild summer and bearable winter and average rainfall is $1410.9 \mathrm{~mm}$. Korea's average temperature is maximum $32^{\circ} \mathrm{C}$ and minimum $17^{\circ} \mathrm{C}$. Total forest area is 350,420 hectares $(59.3 \%)$. The total tribal population is $44.4 \%$. The district is bounded on the north by Shidhi district of Madhya Pradesh on the 
south Bilaspur district on the east by its parent district Surguja and on the west by Shahdol district of Madhya Pradesh [1] [2].

Korea district is one of the north-west district of Chhattisgarh State. The district came into existence on $25^{\text {th }}$ May 1998 in Madhya Pradesh State. Its parent district was Surguja. After the formation of new state of Chhattisgarh on $1^{\text {st }}$ November 2000, the district fell under the Chhattisgarh State [3]-[5].

It is one of the hilly places of Korea district and hilly railway Junction. The forest vegetation of Boridand region is dominated by sal (Shorea robusta A. w. Roth.). The Boridand forest is scattered in Mahanadi forest range in Korea district. Korea district is divided into five blocks: Manendragarh, Bharatpur, Baikunthpur, Sonhat and Khadgawan [6]-[8]. The area of hilly places is thickly populated by various tribal communities like, Baiga, Agaria, Panika, Gonds, Orao, Kol, Korku etc. The density of Baiga and Korkua population is higher than others.

The most live in remote areas of deep forests [9]. The collection of medicinal plants, plant parts and thus uses from the forests are the main source of their livelihood. Due to close contact and association with forest, they have fairly good traditional knowledge of different valuable information of surrounding floras [10]-[12].

They mostly depend on plants or food, fuel, house building, equipments, tools, basketry etc., on one hand, various ethnomedicinal plants or remedies for the alleviation of various ailments on the other hands [13] [14].

\section{Material and Methods}

The present work was carried out in different Plot A, Plot B, and Plot C, of Boridand forest block Manendragarh district Korea, Chhattisgarh on ethnomedicinal drugs in the health care systems of tribes [15].

During the ethno botanical survey (March 2013-February 2014) several local tribals and medicine man have been interviewed for recording the Traditional uses of ethnomedicinal plants species from the surrounding forests. Data was collected in field work proforma (Kumar, 2007) and (Masih, 2013) and (Panigarhi et al., 1989). An attempt was also undertaken in three in-situ plot having an area of on hectors each for ecological assessments [16] [17]. With the help of strip transect method data has been collected and density, frequency, abundance cover relative density relative frequency and relative abundance and cover IVI ( Important Value Index ) diversity contributory diversity percentage etc. were calculated [18]-[20] (Figure 1(a) and Figure 1(b)).

The Traditional information of 41 plants species are tabulated, Botanical name, parts of used and mode of uses [21]-[23].

Some floristic diversity work in this area has been done by workers like Maheswari et al. (1964) Oommacha (1989), Hemadri (1989), Chopra (1956), Masih (2013), Verma (1995), Busia, (2005), Khan, et al (2008), Kala (2005, 2007) where as Miller (1990), Jain (1991), Jain et al. (1994) and Ahirwar (2014, 2011, 2010) highlighted the Traditional Knowledge of plants use by the ethnic peoples [24]-[26] (Table 1).

\section{Results and Discussion}

In the ethno botanical and ecological assessment study a total of 41 plants species belonging to 26 families and 37 plant genera and total number herbacious plants ten and shrubs plants eight and Trees nineteen and climbers only four number of plants have been identified from the in-situ plots. The IVI and diversity of each useful plant species are projected. The plant species like Abrus precatorius, Achyranthes aspera, Adhatoda vesica, Aegle marmelos, Andrographis paniculata and Argemone mexicana, Dalbergia sisso, Butea monosperma etc. were the dominant ethnomedicinal plant species from the in-situ plots. The average IVI value, diversity and number of plants presented [27]-[29].

Highest value of contributory diversity percentage was observed in Butea monosperma (Lamk). (28.35), Abrus precatoris L. (26.58), Delbergia sisso Roxb. (26.14), Desmodium gangeticum (L.) DC. (24.64), Mucuna puriens L. DC. (20.61), Pongimia pinnata (L.) Pierre (18.76), Asparagus recemos Willd. (17.78), Chlorophytm arundinacuem Baker. (14.38), Bauhinia vahlii (Wt. \& Arn.) Benth. (14.26) and Ficus recemosa Linn. (13.66) in Plot A, B and C respectively. Other species which represent less than $10 \%$ value need more protection and conservation for strengthening natural forest resource for future need and requirements of ethnomedicinal plants [30] [31] (Table 2) and (Figure 2).

\section{Conclusions}

The result of the present study indicated that the rich ethnomedicinal knowledge of the community should be 


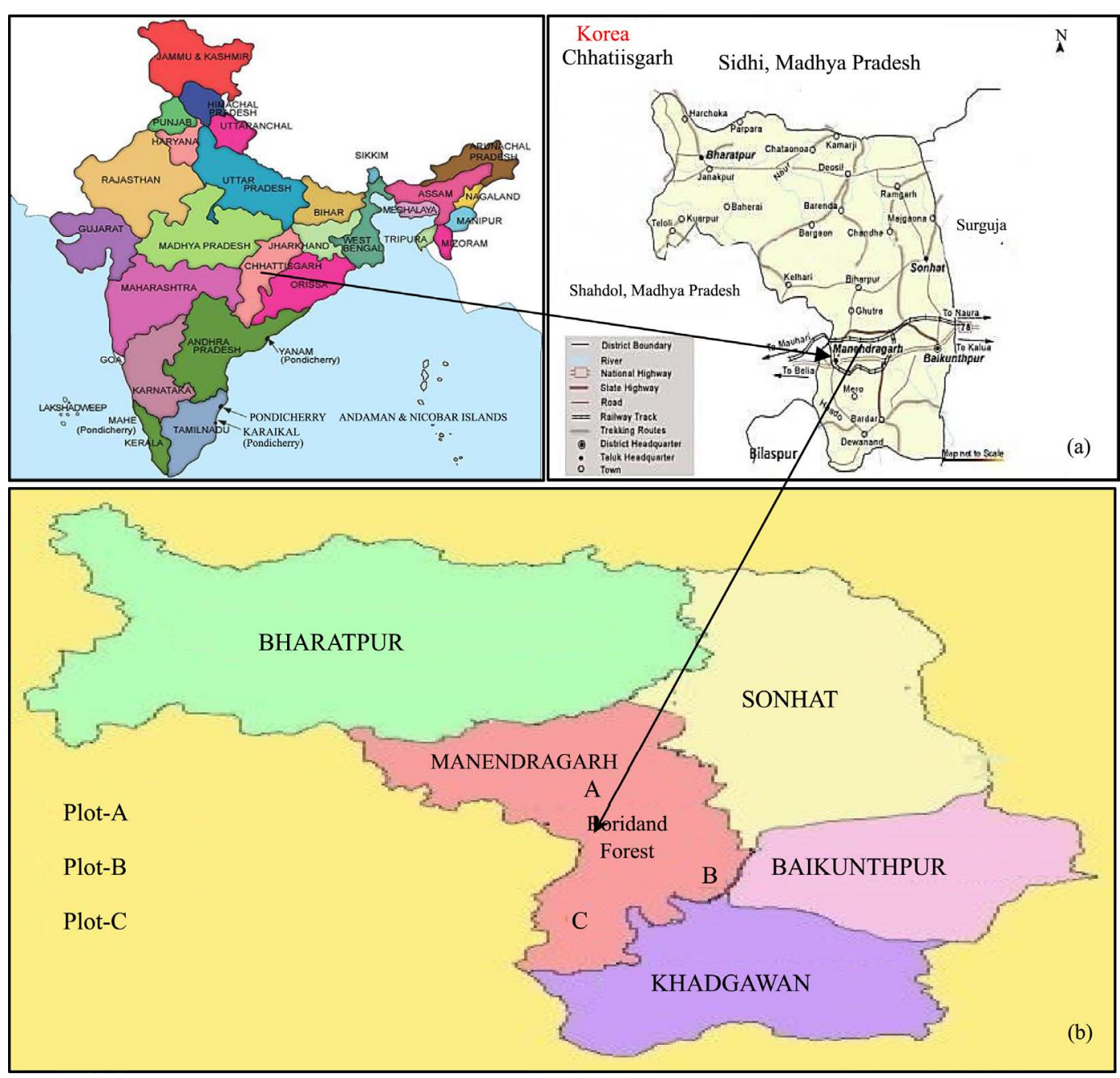

Figure 1. (a) Location map of India in Chhattisgarh State; (b) Representing the study sites of Korea district in Boridand forest.

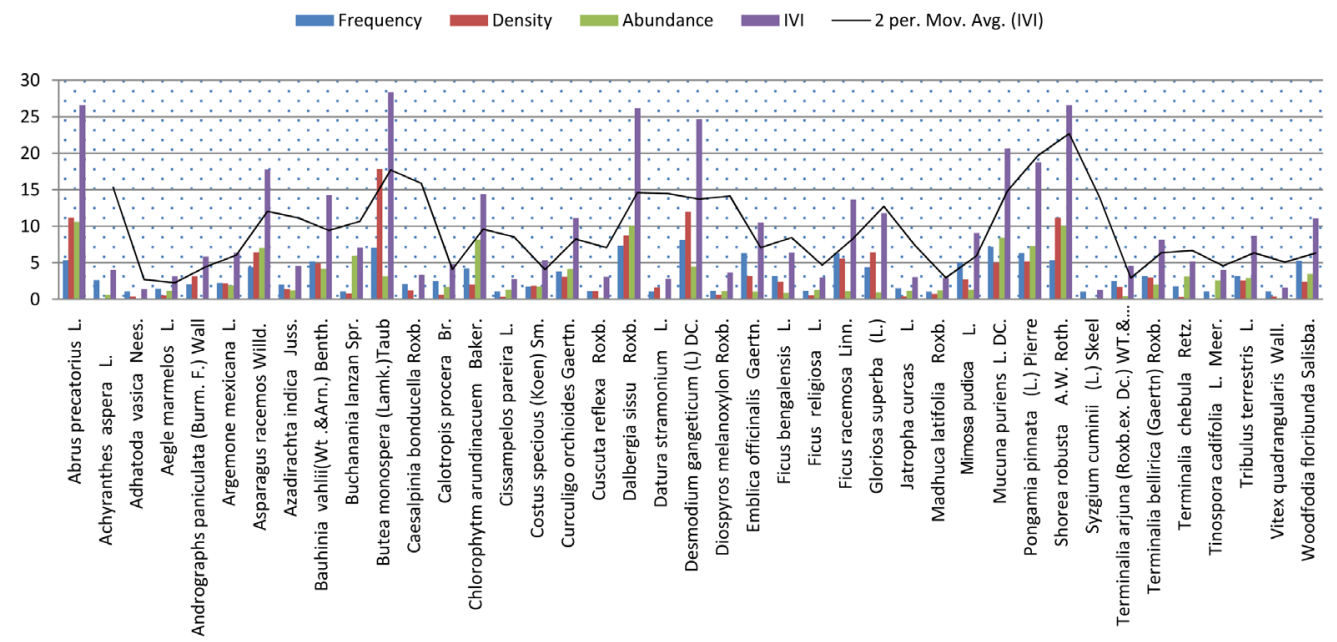

Name of Plant species

Figure 2. Shows IVI of ethnomedicinal plants in Boridand forest district Korea Chhattisgarh, India. 
Table 1. Shows ethno botanical observation of 41 plants species of different study sites of Boridand forest, Korea district, Chhattisgarh, India.

\begin{tabular}{|c|c|c|c|c|c|c|}
\hline S. No. & Botanical name & Local name & Family & $\begin{array}{c}\text { Ethno-botanical \& } \\
\text { ethnomedicinal uses }\end{array}$ & Hb & Study sites \\
\hline
\end{tabular}

1. Abrus precatorius $\mathbf{L}$.

2.

Achyranthes aspera L.

3.

Adhatoda vasica Nees.

Adusa

Acantha aceace

4.

Aegle marmelos $\mathrm{L}$.

Andrographs paniculata

(Burm. F.) Wall

5.

6.

Argemone mexicana L.

Pila Dhatura

7. Asparagus racemos Willd.

8.

Azadirachta indica Juss.
Paperveraceae

Sataveri

Liliaceae

Bhui limb/

Kalmegh

Acanthaceae tea spoonful powder mixed with a glass of cow milk or slightly warm water is given seven days, twice a day after meal.

Latex of plants is suggested to apply one drop in eye lid for the treatment of conjunctivitis, once a day for three days. Root juice of plants, one tea spoon full mixed with equal proportion of cow butter, its given at once for the treatment of eczema and other skin problems.

Decoction of plant is used to treat Uraemia (blood in orine), two times a day, a full of glass till the effect observed. Root powder also used as vital effective.

Seed oil one tea spoon full or crushed seed mixed with glass of water is given 15 days every morning for the treatment of piles. Aqueous solution prepared with bank of plants is given seven days every morning empty stomach, to treat eczema. 


\section{Continued}

9.

\section{Bauhinia vahlii (Wt. \& Arn.) \\ Benth.}

Mohlain

Caesalpiniaceae

10.

Buchanania lanzan Spr.

Chaar

Anacardiaceae

11. Butea monospera (Lamk.) Taub

Palas

Fabaceae

12. Caesalpinia bonducella Roxb.

Gataran

13.

Calotropis procera $\mathrm{Br}$.

Aak

14. Chlorophytm arundinacuem Baker. Safedmusli

15.

Cissampelos pareira L.

Pathar/Paat Korea

16. Costus specious (Koen) Sm.

Keokand

17. Curculigo orchioides Gaertn.

Kalimusli

18. Cuscuta reflexa Roxb.

Amarbel

Cuscutaceae

19. Dalbergia sissu Roxb.

Shisham

Fabaceae
Liliaceace

Costaceace

Hypoxidace ae

(1)

Root paste mixed with a glass of water to prepare aqueous solution and one glass solution is given to treat syphilis or gonourhea for 15

$$
\text { days every morning. }
$$

Baiga use its bark and leaf to treat snake bite. Two are three tender leaf paste, mixed with a glass of water and also mixed 3 - 4 tea spoonful sugar to prepare aqueous solution. One glass solution is given 5 - 7 days at a time to treat Syphilis.

Juice of stem bark, two or three tea spoon full mixed with a glass a water thrice a day is given 3 - 4 days for the treatment of dysentery is summer season.

Leaf Juice 2 - 3 tea spoon full mixed with equal part of Tramarindus indica L. bark ash, two times a day, is given for 15 days to treat asthma or other cough complaints.

Ash of flower mixed with honey one teaspoonful twice a day taken to cure whooping cough and asthma.

Five gram paste of tuber is mixed with water is taken orally three timer a day for treatment of frequent nocturnal emission's.

Baiga use its root to treat fever.

Root decoction used as mild tonic, diuretic and stomach.

Juice of rhizome is used to cure leprosy. The juice a tea spoon full, along with equal part of Azadirachta indica Juss. Bark powder is used two times a day for 15 days to treat jundice.

Baiga use its tuber for a period of 15 days empty stomach for the treatment of impotency.

$\mathrm{H} \quad$ Plot C

Juice of this twinner acts as antiseptic on wounds. Decoction of plant is given for bath to cure skin disease.

Paste of four to five tender leaf is prepared and mixed with a glass of water. Give for a day to treat syphilis or other veneral disease.

Leaf decoction is used by Baiga to cure joint complaints. The slightly warm decoction administered throughout the complaint area till the effect absorbed. Dry leaf used

20. Datura stramonium L. Dhatura Solanaceae for smoking to treat asthma. 


\section{Continued}

21. Desmodium gangeticum (L.) DC.

Balraj

Fabaceace

22.

Diospyros melanoxylon Roxb.

Tendu

Ebenaceae

23.

Emblica officinalis Gaertn.

Amala

Euphorbiaceae

24.

Ficus bengalensis $\mathbf{L}$.

Bad

Moraceae

25.

Ficus religiosa $\mathrm{L}$.

26.

Ficus racemosa Linn.

Gloriosa superba (L.)

Jatropha curcas L.

28.

27.
Bhakranda

Euphorbiaceae
Whole plant is pounded in little water to prepare paste and is given to apply on fore head to cure recurring headache.

Baiga use its dry bark to cure burns. Bark ash mixed with linum oil and applied externally on burn spot till the effect observed.

Its fruits used in fever vomiting, indigestion habitual constipation, digestional troubles.

Tip of aerial roots are crushed and applied on lesions caused due to syphilis. Latex of plant drenches in sugar cake and used 21 days every morning as physical tonic.

Tenders leaves or bark heated with milk and given seven days at a time for the treatment of gonorrhea. Leaves mixed with rice is given to dumb child, so that his tongue will begin to tremble.

Latex is used piles diarrhea and dysentery. Fruits are used in urinary trouble and roots are used as anti-diabitic.

Root powder of about 20 gram mixed with oil of linum is given to animals to treat dysentery.

Baiga use its stem as tooth brush to cure toothache till the effect observed.

Paste of dry flowers are prepared and slightly warm paste is applied on aching muscle to relief pain. Seed oil is used to treat crack on heel. Baiga use its flower paste as ointment in scorpion sting to cure pain and liques prepared by flower used orally.

Seed about 5 gram mixed with equal part of sugar is given daily for three days to treat veneral diseases.

Baiga use its roots decoction to cure joint disease. A glass decoction is given a day for 15 days to treat gout.

Seed oil used to apply externally throughout the affected area for the treatment of seasonal exzema. Baiga use its tender branch as tooth stick to treat toothache and gum troubles.

Fruits are used for dysentery and scorpion sting.

Plot B \& C

Plot B \& C

Plot B \& C

Plot B \& C

Plot A \& C

Plot A \& C

Plot B \& C

T Plot A, B \& C

Sh Plot B \& C

Cl Plot B \& C

T Plot A \& C

Fabaceae

Dipterocarpaceae 


\section{Continued}

\section{Syzgium cuminii (L.) Skeel Jamun Myrtaceae} 35. Terminalia arjuna (Roxb.ex. Dc.) Kahua/Arjun. $\quad$ Combretaceae
Wt. \& Arn.

36. Terminalia bellirica (Gaertn) Roxb. Baheda

Combretaceae

37.

Terminalia chebula Retz. Harra

Combretaceae

Tinospora cadifoli L. Meer.

Gurich

Menispermaceae

39.

Tribulus terrestris L.

Gokhuru

Zygophyllaceae

40
Vitex quadrangularis Wall.

Hadjod

Vitaceace

41. Woodfodia floribunda Salisba.

Dhawai
Seed are dried and powdered about

5 gram powder is dissolved in half

a glass of water and after some

time is given orally twice a day for

15 days to treat diabetes.

Paste of unripe fruit is used as a

stringent while ripe fruit paste is used as purgative.

Paste of two three tenders leaf prepared and is given thrice a day one day one day to cure vomiting and loosemotion.

Ripe fruits paste is used to treat frequent nocturnal emissions in man and unripe fruits powder fried $\mathrm{T}$ Plot A \& $\mathrm{C}$ with butter and taken twice a day to treat constipation.

Baiga use its stem to cure fever.

Decoction is given half a glass

twice a day for week. Bathing in the decoction of plant also suggested. The believes that Evils ran away when see the plant or decoction of the plant.

Decoction of plant is given twice a day for 15 days or till relief for the treatment of spermatorrhea or urin complaints. Baiga use root paste to controle temperature. They apply paste on forehead.

Aqueous solution of plant is given, one glass a day till relief to treat

bone fracture. Decoction of stem is Sh Plot A \& C given twice a day for 15 days to treat irregular menstruration.

\section{T Plot A \& B}

T Plot A \& B

T Plot A \& C

T Plot B \& C

Cl Plot A \& C

Leaves ash well mixed with musterd oil and used for pain.

$\mathrm{T} \quad$ Plot A \& $\mathrm{C}$

Abbreviations: Hb: Habit, H: Herbs, Sh: Shrubs, T: Trees, Cl: Climbers.

Table 2. Important value index, diversity of plants species in various plots at Boridand forest district Korea, Chhattisgarh, India.

\begin{tabular}{|c|c|c|c|c|c|}
\hline S. No. & Botanical name & Plot A & Plot B & Plot C & IVI, Diversity \\
\hline 1. & Abrus precatorius L. & 5.37 & 11.15 & 10.6 & 26.58-II \\
\hline 2. & Achyranthes aspera L. & 2.61 & 0.08 & 0.63 & 4.04 \\
\hline 3. & Adhatoda vasica Nees. & 1.04 & 0.37 & 0.01 & 1.42 \\
\hline 4. & Aegle marmelos L. & 1.45 & 0.52 & 1.16 & 3.13 \\
\hline 5. & Andrographs paniculata (Burm. F.) Wall & 2.07 & 3.14 & 0.06 & 5.81 \\
\hline 6. & Argemone mexicana L. & 2.27 & 2.19 & 1.88 & 6.34 \\
\hline 7. & Asparagus racemos Willd. & 4.37 & 6.41 & 7.0 & 17.78-VII \\
\hline 8. & Azadirachta indica Juss. & 2.0 & 1.4 & 1.18 & 4.58 \\
\hline 9. & Bauhinia vahlii (Wt. \& Arn.) Benth. & 5.16 & 4.92 & 4.18 & 14.26-IX \\
\hline 10. & Buchanania lanzan Spr. & 1.05 & 0.79 & 5.96 & 7.08 \\
\hline
\end{tabular}




\begin{tabular}{|c|c|c|c|c|c|}
\hline \multicolumn{6}{|c|}{ Continued } \\
\hline 11. & Butea monospera (Lamk.) Taub & 7.04 & 17.81 & 3.14 & 28.35-I \\
\hline 12. & Caesalpinia bonducella Roxb. & 2.11 & 1.19 & 0.07 & 3.37 \\
\hline 13. & Calotropis procera Br. & 2.5 & 0.61 & 1.7 & 4.81 \\
\hline 14. & Chlorophytm arundinacuem Baker. & 4.21 & 1.98 & 8.19 & 14.38-VIII \\
\hline 15. & Cissampelos pareira $\mathrm{L}$. & 1.04 & 0.34 & 1.33 & 2.74 \\
\hline 16. & Costus specious (Koen) Sm. & 1.73 & 1.82 & 1.75 & 5.38 \\
\hline 17. & Curculigo orchioides Gaertn. & 3.83 & 3.08 & 4.16 & 11.11 \\
\hline 18. & Cuscuta reflexa Roxb. & 1.07 & 1.08 & 0.19 & 3.06 \\
\hline 19. & Dalbergia sissu Roxb. & 7.37 & 8.73 & 10.04 & 26.14-III \\
\hline 20. & Datura stramonium L. & 1.05 & 1.59 & 0.14 & 2.78 \\
\hline 21. & Desmodium gangeticum (L) DC. & 8.16 & 11.98 & 4.5 & 24.64-IV \\
\hline 22. & Diospyros melanoxylon Roxb. & 1.13 & 0.62 & 1.09 & 3.65 \\
\hline 23. & Emblica officinalis Gaertn. & 6.32 & 3.17 & 1.02 & 10.51 \\
\hline 24. & Ficus bengalensis L. & 3.16 & 2.38 & 0.85 & 6.39 \\
\hline 25. & Ficus religiosa $\mathrm{L}$. & 1.16 & 0.55 & 1.29 & 3.00 \\
\hline 26. & Ficus racemosa Linn. & 6.31 & 5.55 & 1.08 & 13.66-X \\
\hline 27. & Gloriosa superba (L.) & 4.37 & 6.41 & 1.0 & 11.78 \\
\hline 28. & Jatropha curcas L. & 1.5 & 0.38 & 1.15 & 3.03 \\
\hline 29. & Madhuca latifolia Roxb. & 1.02 & 0.71 & 1.18 & 2.91 \\
\hline 30. & Mimosa pudica L. & 5.05 & 2.69 & 1.31 & 9.05 \\
\hline 31. & Mucuna puriens L. DC. & 7.18 & 5.02 & 8.41 & 20.61-V \\
\hline 32. & Pongamia pinnata (L.) Pierre & 6.31 & 5.16 & 7.29 & 18.76-VI \\
\hline 33. & Shorea robusta A.W. Roth. & 5.38 & 11.15 & 10.06 & 26.58 \\
\hline 34. & Syzgium cuminii (L.) Skeel & 1.02 & 0.09 & 0.16 & 1.27 \\
\hline 35. & Terminalia arjuna (Roxb.ex. Dc.) Wt. \& Arn. & 2.5 & 1.69 & 0.43 & 4.62 \\
\hline 36. & Terminalia bellirica (Gaertn) Roxb. & 3.17 & 3.0 & 2.02 & 8.19 \\
\hline 37. & Terminalia chebula Retz. & 1.77 & 0.28 & 3.12 & 5.17 \\
\hline 38. & Tinospora cadifolia L. Meer. & 1.05 & 0.04 & 2.59 & 4.04 \\
\hline 39. & Tribulus terrestris $L$. & 3.16 & 2.58 & 2.92 & 8.66 \\
\hline 40. & Vitex quadrangularis Wall. & 1.04 & 0.37 & 0.17 & 1.58 \\
\hline 41. & Woodfodia floribunda Salisba. & 5.26 & 2.38 & 3.43 & 11.07 \\
\hline
\end{tabular}

documented and preserved properly for better utilization of the plant resources. Particularly, there is a need of detail study of the ethnomedicinal plants used by the tribals community with possible investigation which may highlight the true value of these plant species so that they can be managed and conserved for the benefit of the local community as well as for the welfare of mankind.

The present study represents of 41 ethnomedicinal plants species in Boridand forest area which belong to 26 families and 37 plant genera. There are 26 families under to herbs $24 \%$, shrubs $20 \%$, trees $46 \%$, and climbers $10 \%$ identified and total 26 families in the highest diversity of family Fabaceae, Moraceae and Liliaceae were reported (Figure 3 and Figure 4). We also represent some ethnomedicinal plants, vegetation of forest, Baiga 
tribals huts and tribal healers photographs in Boridand forest district Korea, Chhattisgarh, India (Figure 5-13).

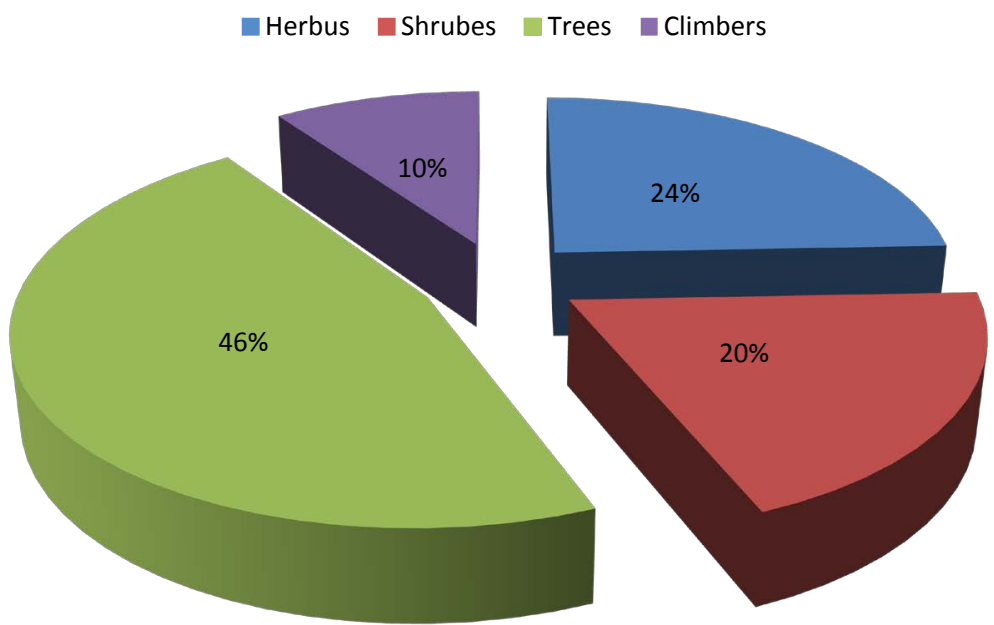

Figure 3. Distribution of ethnobotanical species in Boridand forest.

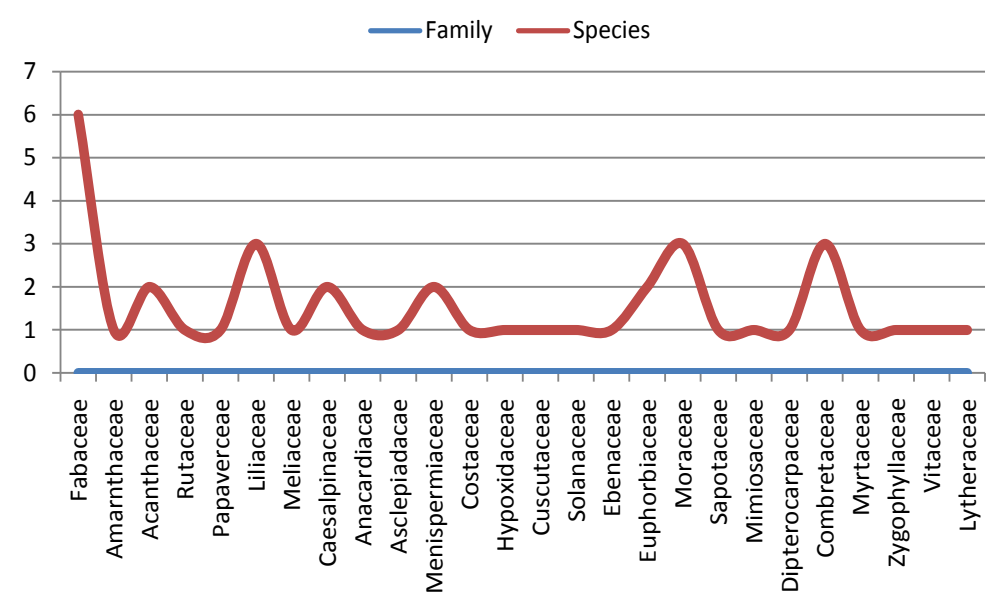

Figure 4. Showing comparative distribution of family and plant species in Boridand forest.
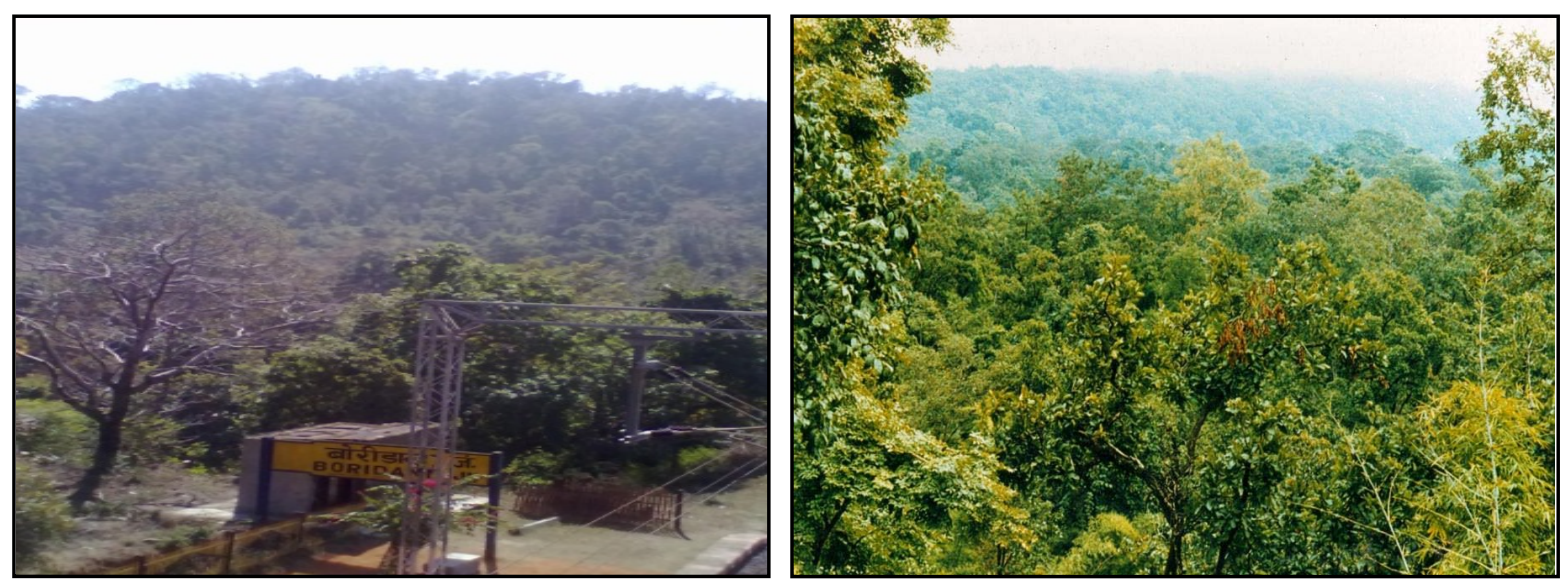

Figure 5. Vegetation of Boridand forest district Korea, Chhattisgarh, India. 

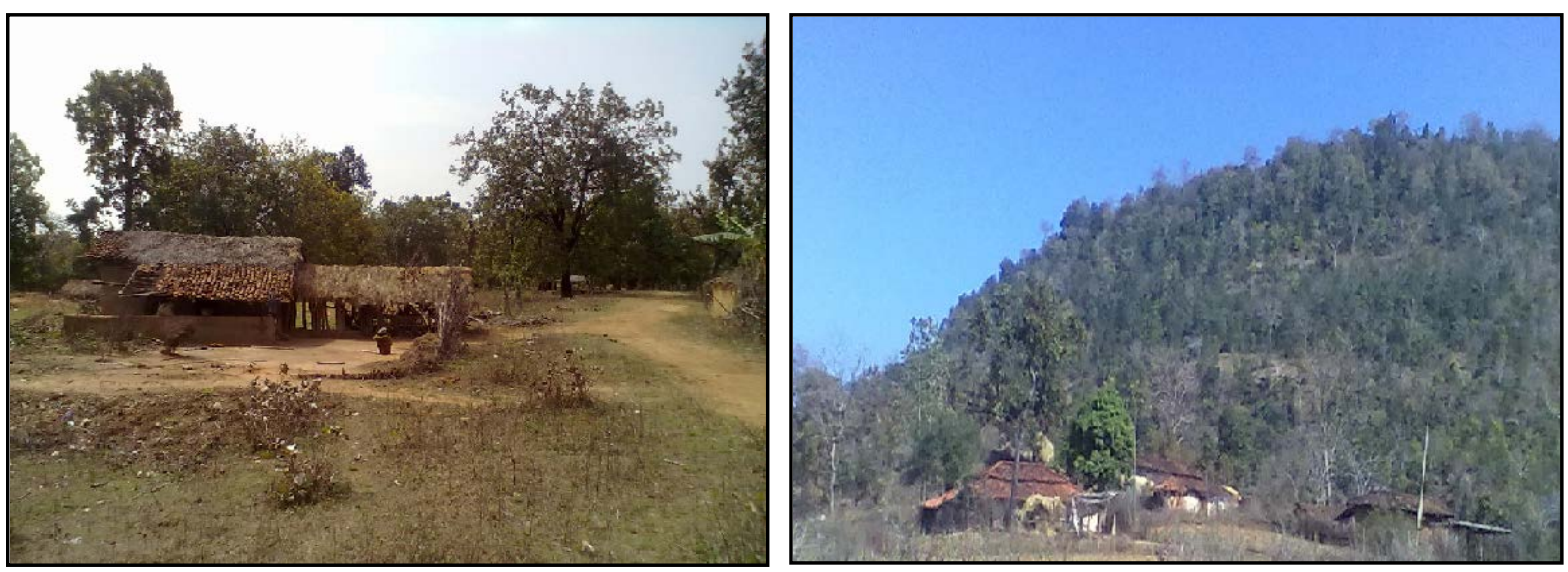

Figure 6. Location of Baiga's tribes hut's.
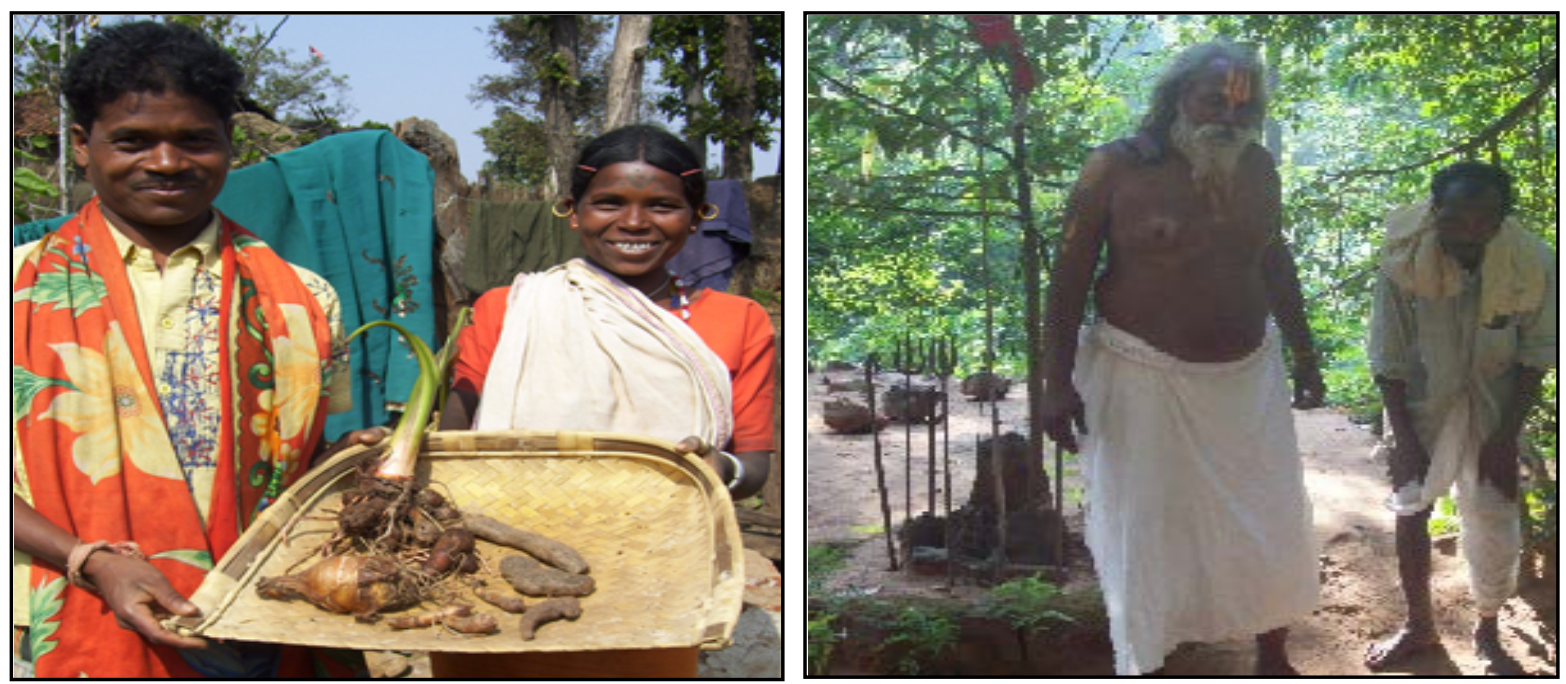

Figure 7. Showing on ethnomedicinal plants of Baiga tribes and tribal healer.

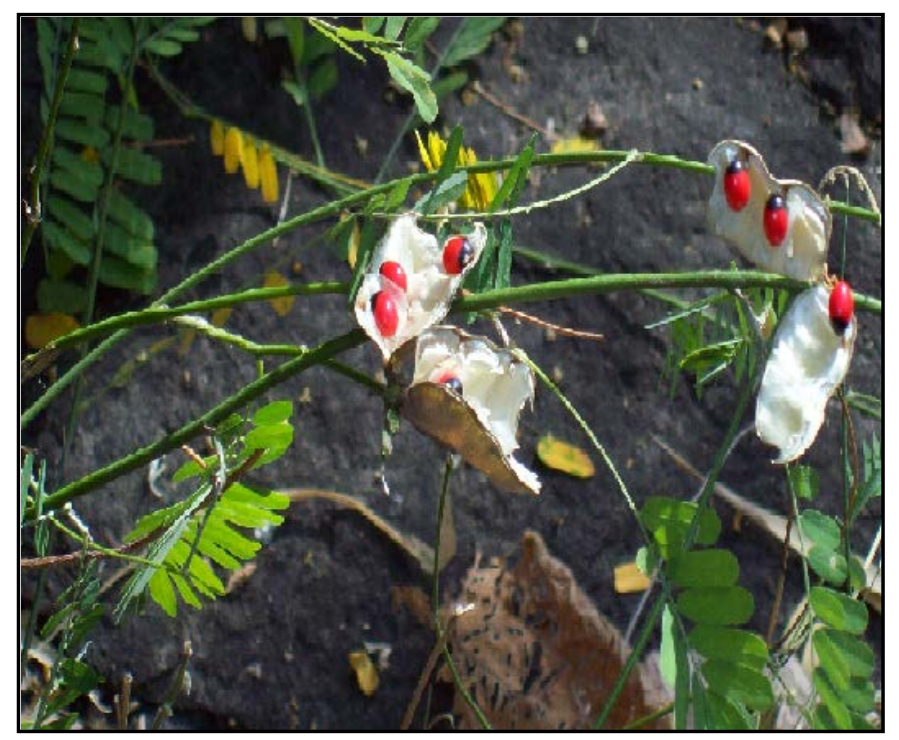

Figure 8. Abrus precatorius L. 


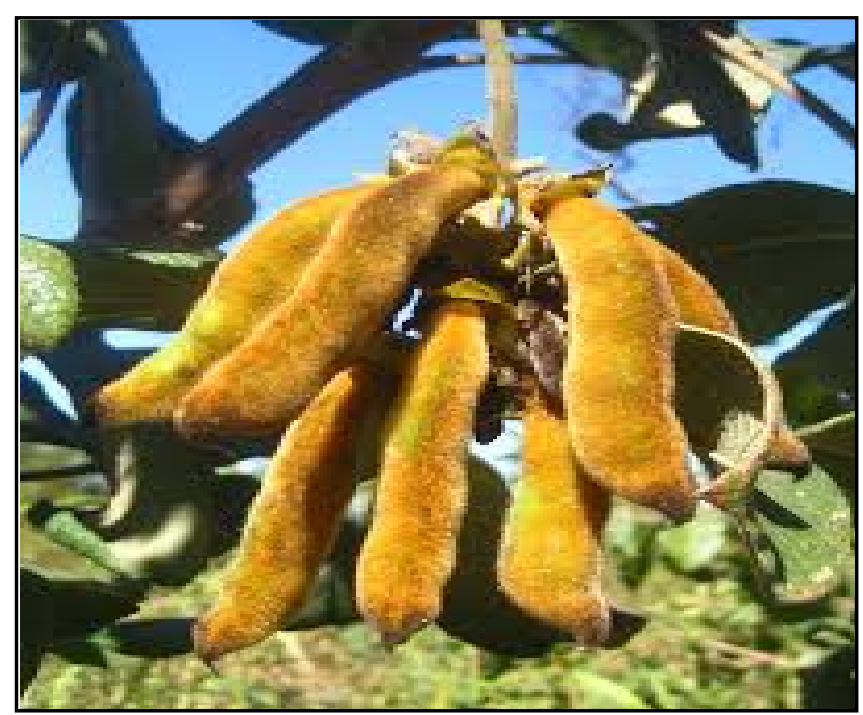

Figure 9. Mucuna puriens L. DC.

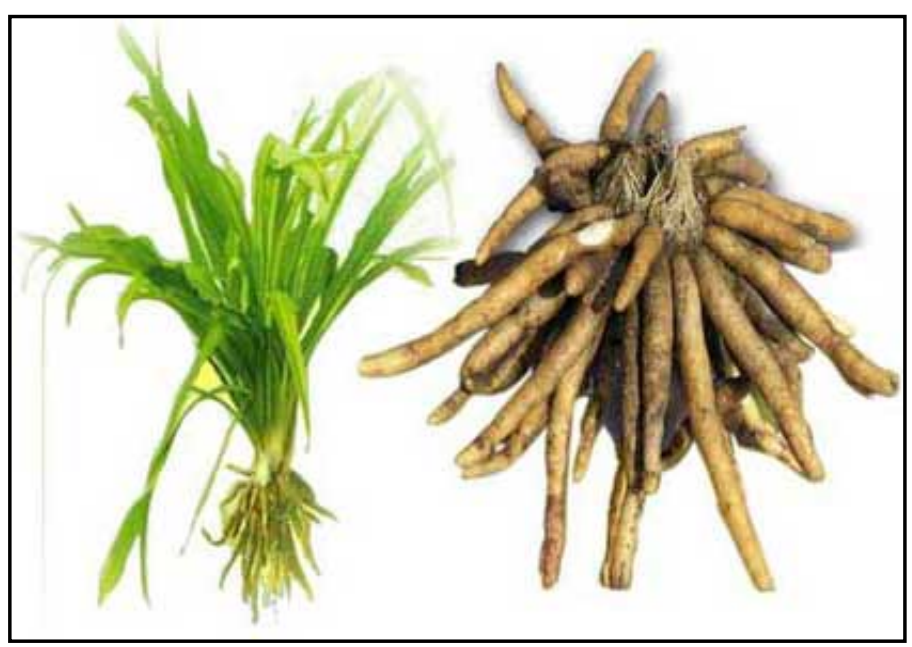

Figure 10. Chlorophytm arundinacuem Baker.

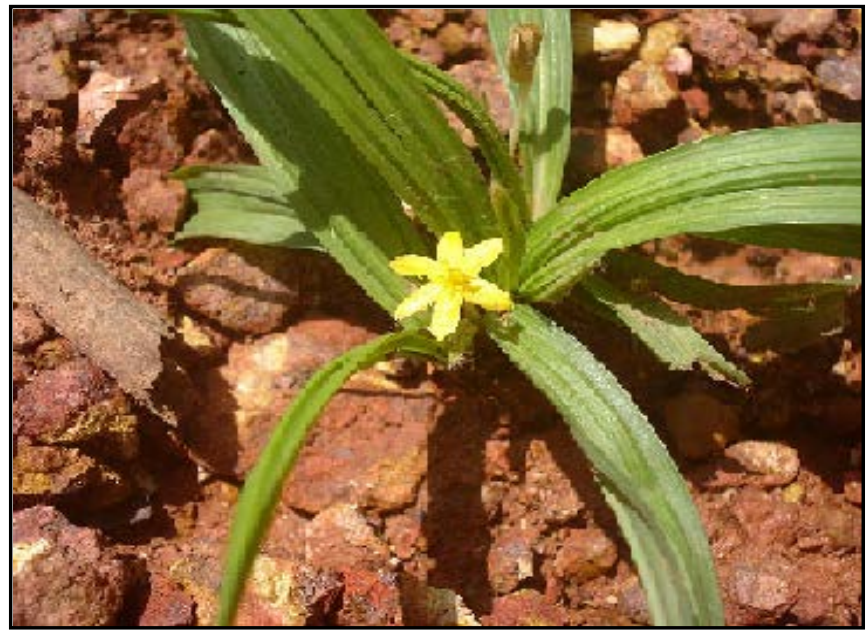

Figure 11. Curculigo orchioides Gaertn. 


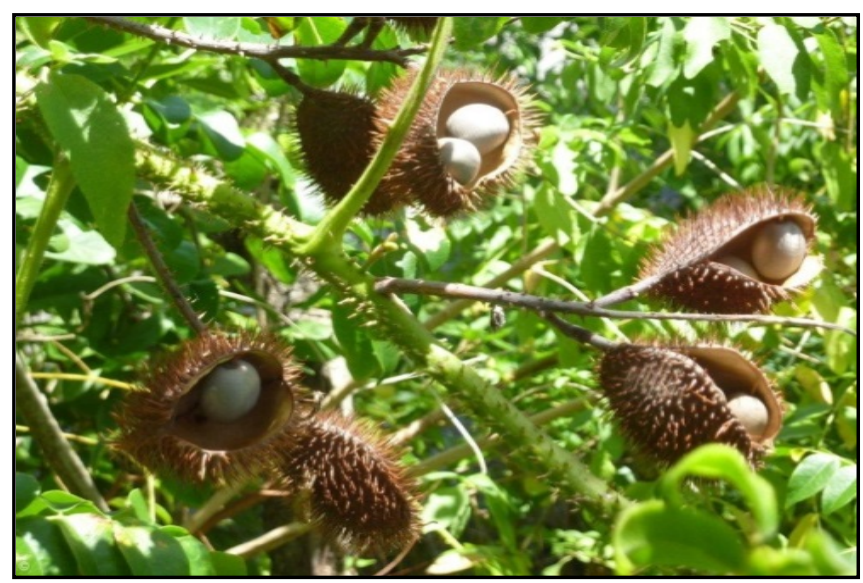

Figure 12. Caesalpinia bonducella Roxb.

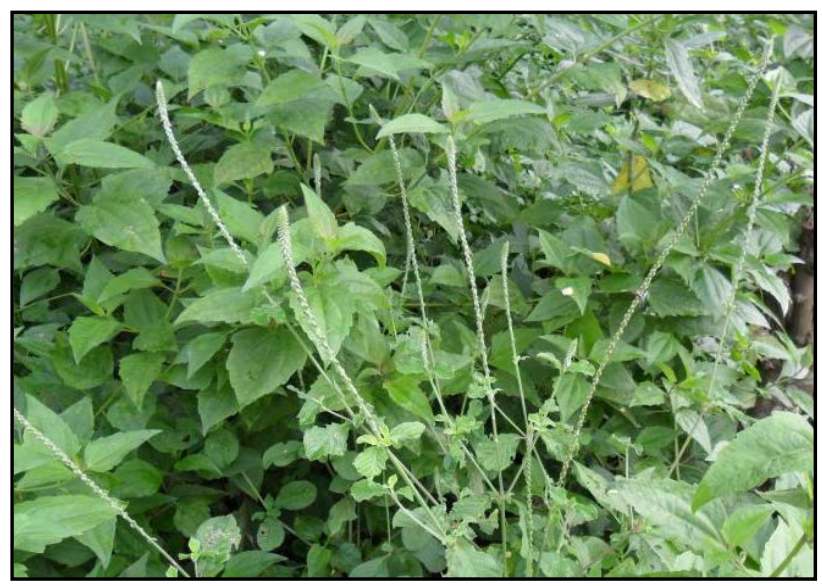

Figure 13. Achyranthes aspera L.

\section{Acknowledgements}

Author is thankful to tribal and rural people for their co-operation and sharing their knowledge during study period.

\section{References}

[1] Agrawal, D.P. (1997) Traditional Knowledge Systems and Western Science. Current Science, 73, 731-733.

[2] Ahirwar, R.K. (2010) A Survey of Medicinal Plants Used by Tribals of Anuppur District, Central India. Indian Journal of Applied Pure Biology, 25, 227-230.

[3] Ahirwar, R.K. (2011) Ethnomedicinal Plants Studies in Jaitpur Forest range of Shahdol, District, Central India. Plant Science, 24, 681-684.

[4] Ahirwar, R.K. (2014) Utilization of Medicinal Plants by the Tribes of Bhatiya, District Shahdol, Madhya Pradesh. International Journal of Scientific and Research, 3, 149-151.

[5] Ahirwar, R.K. (2010) Ethnomedicinal Uses of Plant Roots from Shadol District of M.P. India. Indian Journal of Applied Pure Biology, 25, 71-76.

[6] Ahirwar, R.K. and Girja, K.S. (2011) Some Anti Diabetic Plants from Dindori District of Madhya Pradesh (India). Indian Journal of Applied Pure Biology, 26, 269-271.

[7] Biswas, T.K. and Mukherjee, B. (2003) Plant Medicines of Indian Origin for Wound Healing Activity: A Review. International Journal of Lower Extremity Wounds, 2, 25-39. http://dx.doi.org/10.1177/1534734603002001006

[8] Busia, K. (2005) Medical Provision in Africa-Past and Present. Phytotherapy Research, 19, 919-923.

http://dx.doi.org/10.1002/ptr.1775 
[9] Chopra, R.N., Nyar, S.L. and Chopra, I.C. (1956) Glossary of Indian Medicinal Plants. Council of Scientific and Industrial Research, New Delhi.

[10] Hemadri, K. and Rao, S.S. (1989) Folk Medicine of Bastar. Journal of Ethnobotany, 1, 61-66.

[11] Jain, S.K. (1963) Observation on the Tribals of Madhya Pradesh. Vanyajati, 11, 177-183.

[12] Jain, S.K. (1991) Dictionary of Folk Medicines and Ethnobotany. Deep Publications, New Delhi.

[13] Jain, S.K. (1981) Glimpses of Ethnobotany. Oxford \& IBH, New Delhi.

[14] Jain, S.K. (1965) Medicinal Plant Lore of the Tribals of Bastar. Economic Botany, 19, 236-250. http://dx.doi.org/10.1007/BF02914310

[15] Jain, S.P. and Singh, S.C. (1994) Ethno-Medico-Botanical Survey of Ambikapur, Madhya Pradesh. IV ICE, Lucknow.

[16] Khan, A.A., Agnihotri, S.K., Singh, M.K. and Ahirwar, R.K. (2008) Enumeration of Certain Angiospermic Plants Used by Baiga Tribe for Conservations of Plants Species. Plant Archives, 8, 289-291.

[17] Kirtikar, K.R. and Basu, B.D. (1999) Indian Medicinal Plants. Vol. 3, International Book Distributors Book Sellers and Publishers, Deheradun.

[18] Kumar, K. (2007) Working Plan of North Surguja, Ambikapur. Forest Department, Government of Chhattisgarh, Raipur.

[19] Khan, A.A., Agnihotri, S.K., Singh, M.K. and Ahirwar, R.K. (2008) Observation of Certain Plants Used in Skin Diseases by Baiga Tribes of Mandala District. Plant Archives, 8, 283-284.

[20] Kala, C.P. (2007) Local Preferences of Ethno-Botanical Species in the Indian Himalaya: Implications for Environmental Conservation. Current Science, 93, 1828-1834.

[21] Kala, C.P. (2005) Indigenous Uses, Population Density and Conservation of Threatened Medicinal Plants in Protected Areas of the Indian Himalayas. Conservation Biology, 19, 368-378. http://dx.doi.org/10.1111/j.1523-1739.2005.00602.x

[22] Maheswari, J.K. (1964) A Contribution to the Flora Kanha National Park, Madhya Pradesh. Bulletin of Botanical Survey India, 5, 117-140.

[23] Masih, V., Sahu, P.K. and Singh, M. (2013) Observation on Ethno-Medicinal Herbs of Dantewada, Chhattisgarh, India. International Journal of Drug Discovery and Herbal Research, 3, 644-648.

[24] Miller, N.N. (1990) Traditional Medicine in East Africa. America Universities Field Staff Report, Vol. 22, 1-15.

[25] Oommachan, M. and Masih, S.K. (1989) Ethnobotanical Observations on Certain Forest Plants of Jabalpur (M.P.). Indian Journal of Pure and Applied Biology, 4, 73-78.

[26] Panigarhi, G. and Murti, S.K. (1989) Flora of Bilaspur District of Madhya Pradesh. Vol. 1, 46-71.

[27] Smvastar, S. (1996) The Flora of Western Tribals of Madhya Pradesh. Scientific Publishers, Jodhpur, 26-28.

[28] Singh, N.P., Khanna, K.K., Mudgal, V. and Dixit, R.D. (2001) Flora of Madhya Pradesh. Vol. 3, Botanical Survey of India.

[29] Tiwari, K.P., et al. (1995) Flora of Amarkantak for Detailed Project Formation to Constitution Amarkantak Biosphere Reserves. Draft Project, SFRI, Jabalpur.

[30] Verma, P., Khan, A.A. and Singh, K.K. (1995) Traditional Phytotherapy among the Baiga Tribe of Shahdol District of Madhya Pradesh, India. Ethnobotany, 7, 69-73.

[31] World Health Organization (2007) WHO Monographs on Selected Medicinal Plants. Vol. 3, Geneva. 
Scientific Research Publishing (SCIRP) is one of the largest Open Access journal publishers. It is currently publishing more than 200 open access, online, peer-reviewed journals covering a wide range of academic disciplines. SCIRP serves the worldwide academic communities and contributes to the progress and application of science with its publication.

Other selected journals from SCIRP are listed as below. Submit your manuscript to us via either submit@scirp.org or Online Submission Portal.
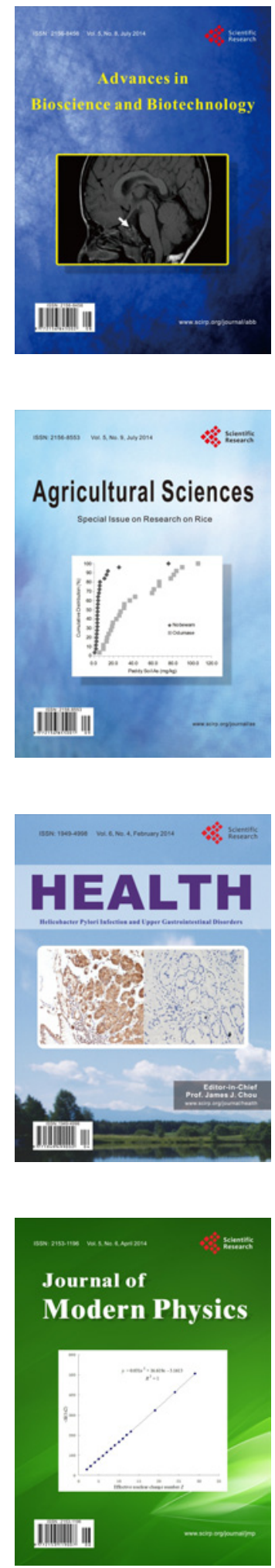
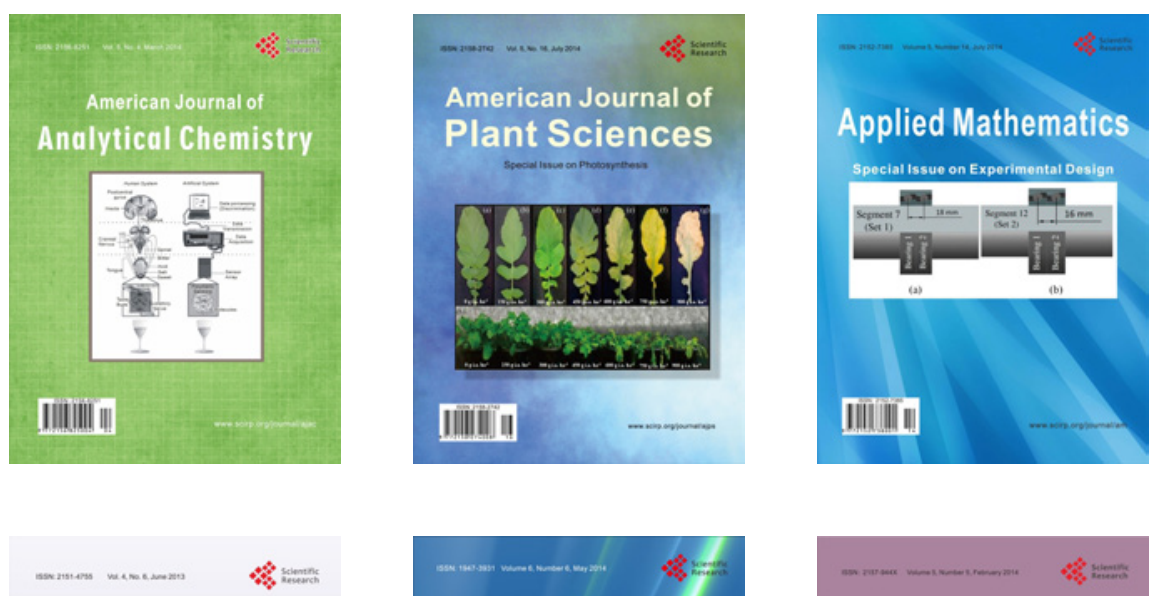

Creative Education
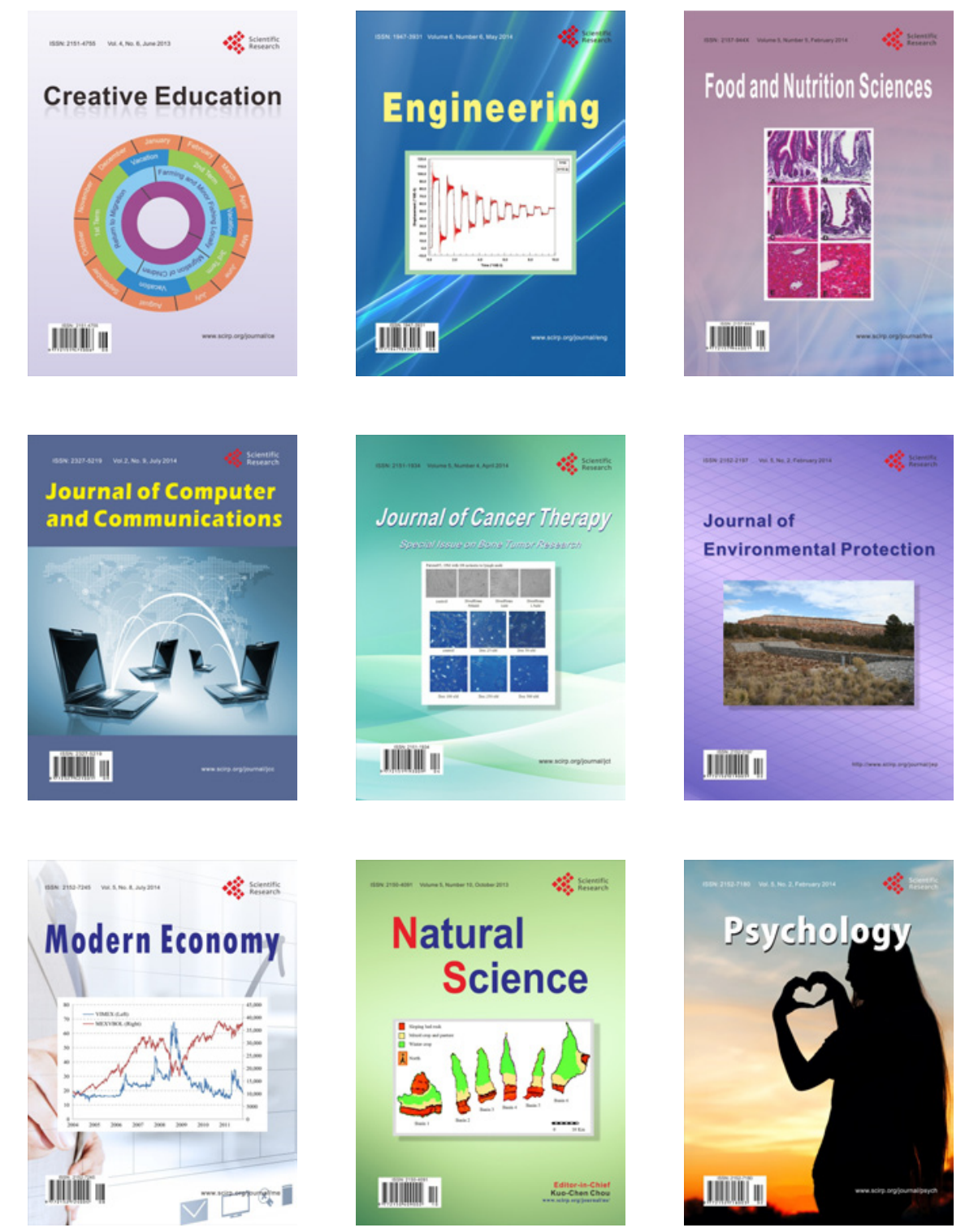